\title{
HUMAN RIGHTS BEYOND DICHOTOMY BETWEEN CULTURAL UNIVERSALISM AND RELATIVISM
}

\author{
EDNA RAQUEL HOGEMANN ${ }^{1}$
}

\begin{abstract}
The consolidation of relations of global society requires the progressive establishment of a global legal system, consisting of a system of rules - precisely, human rights - as the source and evaluation criteria of positive national rights. This essay aims to contribute to some extent using reflective dialectical methodology, establishing logical-argumentative criteria, based on the dialogue between authors to exercise a critical reflection of the official narrative on the universality of human rights, in addition overcoming the universalism/relativism dichotomy eurocentricaly established by a theory of human rights between universalism and cultural relativism.
\end{abstract}

Keywords: human rights; universality; multiculturalism; cultural relativism

Summary: 1. Introdution. 2. The historicAl-IDEOLOGICAL CONSTRUCTION OF HUMAN Rights. 3. EUROCENTRISM IN THE DISCOURSE OF HUMAN RIGHTS. 4. THE ISSUE OF MULTICULTURALISM AND HUMAN RIGHTS. 5. CONCLUSION

\section{InTRODUTION}

There are strong criticisms of the attempts to create a world political order based on the defense of human rights, allowing international organizations and major powers to implement a centralized policy of "humanitarian" intervention, situated above the sovereignty of States, using even of war resources if necessary. In this line of argument, there are those who accuse the West of using "human rights rhetoric" to cover up their true political and economic interests and, through that discourse, impose its policies on the rest of the world. The process leading to the creation and consolidation of human rights is contemporary to the expansion of Europe and the West over the whole world and inextricably linked to this process and its contradictions.

If, in the so-called West, the consolidation of some fundamental rights was the result of many struggles and conflicts and wars, non-European countries excluded from this process since the beginning and not infrequently participated as victims. The approach to the issue of human rights comes as a more tortuous issue to jurists faced with dilemmas that have assumed an enormous degree of importance with the intra-frontier and international community and which, at the same time, have not yet achieved unity of thought that allows its organization to ensure universal protection.

It is, therefore, relevant to the establishment of a set of universal human rights to try to find, at least, a minimum set of guarantees capable of assuring the dignity of the

\footnotetext{
${ }^{1}$ UFRJ and Permanent Professor of the Graduate Program in Law and Dean, at the Federal University of the State of Rio de Janeiro - UniRio. E-mail: ershogemann@gmail.com
} 
human person. The very notion of dignity is problematic for the solution of this impasse, as each country, and within each of these countries, each culture sheltered by them, tends to establish its own conception of human dignity. To discuss a theory of human rights necessarily leads to a reference to the juridical theory of this class of rights, enshrined by a range of treaties, conventions and laws that define and regulate both national and international, guarantors of the fundamental rights of the human person; secondly, not least, the necessary reference to the theoretical basis of human rights, lacking a reflection that takes into account all the issues that are intrinsic and extrinsic to them: cultural, social, political, religious, gender, ethnic, economic, mental, technological, biotechnological, among others, and no less relevant, to fail to conceive placidly as if ultimate, universal and perfect truth were the various social facts politically placed in the world today.

Therefore, it is a task, by scientific vocation, faced by the theory and practice of human rights, to overcome these social situations in terms of values and norms, which ensure the dignity of the human person. Although the ideal of human rights seeks a universality of consecration and respect in the rights that must be fulfilled, the different cultures, religions and customs of the different country show that the practice of human rights is not so simple, on the contrary, it is difficult.

However, the movement of globalization and the international benefits that the countries receive, necessitate the incorporation of human rights norms. The fulfillment of norms concerning human rights, even when these are not in keeping with the culture of their country, leads to the conclusion that in this action lies a true moral content, which, in Kant's eyes, means fulfillment not for duty, but out of duty. Human rights have a highly moral content; all the declarations related to this right prescribe norms of conduct to be fulfilled by the states that they sign and even, to a certain extent, to their non-signatories, since the UN has unconventional mechanisms in case of violation to human rights in countries. Then the questions begin: what is the foundation of human rights? How is the situation between the universality sought by the Universal Declaration of Human Rights and the traditions derived from different cultures? There are several currents, and this essay aims at examining, according to parameters of contemporary anthropology, multiculturalism, especially in democratic societies of law, to express the legitimacy and effectiveness of new juridicities, as well as to compare national and international norms, such as the International Criminal Court and the European Court of Human Rights, understood as elements of reaffirmation of the social commitment to human rights and to the practices of citizenship as a space for struggle and human emancipation. In this perspective, it is intended to reiterate that the construction of a theory justifying human rights requires overcoming the dichotomy of universalism and relativism.

\section{THE HISTORICAL-IDEOLOGICAL CONSTRUCTION OF HUMAN RIGHTS}

The Universal Declaration of Human Rights, signed in 1948, reported what would be the beginning of a new era in which the assumption of the elevation of human rights would be of interest to the international community. This was what the legion of the oppressed, detested, massacred and persecuted from the outside world expected. 
This declaration was of unequivocal importance, which is why his text was immediately referred to by some constitutions. But, unfortunately, it is not legally enforceable for all States to observe; this situation led to the need for the elaboration of a number of protocols that strengthened and gave particularity to the rights present in its text, with a view to their recognition and effectiveness by the States.

Between 1945 and 1966, a number of key international human rights documents were drawn up, granting them mandatory legal status, a hard law, with the ratification of the International Covenant on Civil and Political Rights and the International Covenant on Economic, Social and Cultural Rights, both of 1966, in addition to the optional protocols to the International Covenant on Civil and Political Rights, which constitute the International Bill of Human Rights.

About this Declaration, Comparato (2001, p. 226) teaches that:

The Universal Declaration of Human Rights was drafted under the impact of the atrocities committed during World War II. Taking up the ideals of the French Revolution, it represented the historical manifestation that the recognition of the supreme values of equality, freedom and fraternity among men had finally been formed. The crystallization of these ideals in effective rights will be progressively, at the national and international level, as the result of a systematic effort of human rights education.

Barreto (2010, p.8) argues that human rights "first became a process of recovering the foundations of the legal system in the moral argumentation".

In order to do so, it was necessary to substitute the normative totality intended by the sovereign's will for a set of original rights, an expression of natural freedom and equality between men. It is important to point out that this set of rights starts from a presumption of ownership of a subject conceived through a Thomist vision of person, that is, man would be composed of spiritual and bodily substance. This conception of person led to the elaboration of the principle of the essential equality of every human being, notwithstanding individual and group differences, biological or cultural. For Comparato (2001, p.19), it is this essential equality of the person that forms the nucleus of the universal concept of human rights. "The expression is not pleonastic, since these are rights common to every human species, every man as a man, which result from his own nature, and are not mere political creations."

The human being has no price, but a dignity, since it does not allow substitution for another equivalent, being an end in itself. According to Kant (1995, p. 71), "in the realm of ends everything has either a price or a dignity. When a thing has a price, it can be put instead of any other as equivalent; but when a thing is above all price, it does not allow equivalent, so it has dignity." The author goes on to explain that what constitutes the condition only thanks to anything can be an end in itself, has not only a relative value, that is, a price, but an intimate value, i.e., dignity. Morality and humanity are the only 
things that have dignity. Now every man has dignity, for humanity as a species, every human being, in his individuality, is properly irreplaceable, and can not be exchanged for anything, being an end in itself.

The term "human rights" is not unanimous in doctrine. There are authors who prefer other nomenclatures. An example of this is that according to Fernandez (1991, p. 78), the expression that best defines the current theoretical situation of human rights is "fundamental rights of man", for the following reasons:

It is intended to show that every person has moral rights because they are so and that they must be recognized and guaranteed by society, by law and by political power without any kind of social, economic, legal, political, ideological or cultural discrimination. or sexual. These rights are extremely connected with the idea of human dignity and are at the same time the conditions for the development of this idea of dignity. (Fernandez 1991, p. 78)

The French doctrine commonly uses the term "public liberties"; the German one uses more frequently the term "subjective public rights". The Charter of the United Nations uses both the term "human rights" (preamble and article 56) and "fundamental freedoms" (art. 56 (c)).

Human rights exist even without positive recognition, that is, there is no need for any law to prescribe it so that people are holders of human rights. Human rights are not precisely related to the natural characteristics of man, nor to his original position of society, "because they are independent of any legislation, legal title or tradition. Rights that do not need to be attributed are irrevocable and inalienable" (Barreto, 2010, p.11). Complementing this reasoning, for the author, human rights are an expression that combines law and morality and express, since the eighteenth century basically:

respect for the dignity of the human person, the right to life, the equality of all men before the law, security, freedom of expression, access to education and the right to political participation. All these rights are based more on the feeling of an original right than on the expression through the positive sovereign law. These rights, in the historical process of their affirmation, served and serve to evaluate the laws from the angle of their ethical foundation and, therefore, to legitimize or delegitimize them. (Barreto, 2010, p.11).

Fernandez (1991, p. 79) states that "we can only consider human needs as human needs that demand their satisfaction unconditionally." According to Ramos (2005, p.33), "human rights norms, vague or full of indeterminate concepts, incessantly need the judicial realization of their scope and meaning." This is due, in particular, to the search for universality. The less a norm is abstract, the more specific is its scope, which renders the universality sought by human rights practically impossible. 
Shivji (1989, p.8) warns against the danger of legalizing human rights, highlighting the ideological and historical components in a colonialist bias of these rights. That is it addresses the issue in a socio-historical and non-normative context.

The author uses a historical and discursive approach, which consists of a study of the rights, from a philosophical perspective, from a social, economic and political context, thus allowing a reasoning and reflection of the various rights, namely, the concepts of equality, self-determination and life within a geopolitical framework of peoples. It adopts a historical approach in that it analyzes the evolution of human rights from the historical context in which they were created and developed. It states that the concepts of equality and rights have an ideological basis. Thus, it adopts a discursive approach, insofar as it analyzes the ideologies of the world powers, which were the basis of the appearance and legalization of these rights.

From a historical-ideological construction, the author explains the ideological separation between developed and developing countries. On the other hand, Baxi (2006) adopts a dialectical approach of inclusion and exclusion. That is, the author considers that the construction and deconstruction of norms, standards and values of human rights belong to a dialectical process and inclusion and exclusion. The author refers to intertextuality as having a political component, and several hierarchical constructions of human rights exclude the textuality of the same rights. There is a need here for the existence of points of contact between positions, thus proposing a union. Neither of these approaches has a normative aspect, being certain that, for Shivji, the author considers there is, for example, a contextual element of socio-historical order that is not considered.

Baxi (2006) points out that every act of writing and interpreting implies questioning the notions of authorship and authority of a text. For this, the author relies on Michel Foucault's thought in which the very notion of author is problematized in the face of the constant proliferation of possibilities of interpretation. This is because, for Baxi (2006, p. 170) "indeterminate power of interpretive communities has indeed been far-reaching not only because its 'authorship' remains multitudinous in case of treaties and instruments but also improvised as in the case of usual Reading of the international as a source of law Donnelly (2006, p.68) points out some interesting points in this interpretation of human rights, namely: the existence of a legal consensus at the international level regarding regard to human rights, relatively superficial and not very comprehensive. Beyond the fact that the law reflects or materializes the interest of the powerful. Donnelly $(2006$, p.69) points to the exclusionary process of defining human rights, in that it leaves out individuals and groups of people, both at the national and transnational levels.

In a especial way, it is important to emphasize what Moyn says in his publication named Christian Human Rights. He writes, "[T]he general thesis of Christian Human Rights is that through this lost and misremembered transwar era, it is equally if not more viable to regard human rights as a project of the Christian right, not the secular left. Their creation brought about a break with the revolutionary tradition and its droits de l'homme, or - better put - successful capture of that language by forces reformulating their conservatism" $(2015$, p. 8$)$. 
Moyn considers that human dignity has become a central argument in Christian political discourse since 1937. For this author, both the Christian Democratic parties as well as the Catholic Church itself and the Protestant churches took charge of promoting the discussion around religious piety in the years immediately prior to the outbreak of World War II. On the other hand, with the end of the war, the governments of Western Europe tried to highlight this process. Thus, human rights end up gaining public space as a result of these two movements at the beginning of the Cold War. And he concludes:

In the 1940s, as much as in and through some of em contemporary legacies, Christian human rights have been not so much about the inclusion of the other as about policing the borders and boundaries on which threatening enemies loom. And so the story of Christian human rights shows how our premier pincipeles have a complex itinerary. Like all inheritances, it is Worth tough criticismo rather than unreflective admiration. $(2015, \mathrm{p} .04)$

In The Conservative Human Rights Revolution, Marco Duranti (2017) offers an analysis of the emergence of the European Convention on Human Rights (ECHR) and the European Court of Human Rights, in which the author shows a very close perspective and argues that conservatives of England and France (including French Catholics and British socialists), after World War II, conceived this document as a way of restricting democratic capacity of elected governments to implement leftist policies, aiming at the exclusion of communists from the European project, on the one hand and, on the other, the refutation of equal safeguard to colonized people. "If there was any revolutionary turn in the history of human rights", evinces Marco Duranti (2017, p.23), it was both European and conservative in nature.

Precisely because of this cultural and historical context, for many the banner of the universality of human rights remains questioned. ${ }^{2}$ This is because the historical understanding of the struggle for human dignity should consider the efforts of societies subjugated by tyranny and European imperialism. Unfortunately, such efforts are not part of the official narrative of human rights.

\section{EUROCENTRISM IN THE DISCOURSE OF HUMAN RIGHTS}

Fernandez (1991, p. 79) states that "human rights have their anthropological foundation in the idea of human needs. Its recognition, exercise and protection of these rights are intended to satisfy a series of requirements that are considered necessary for the development of a dignified life "From this idea of human needs, the most diverse foundations that are the basis for human rights arise.

\footnotetext{
${ }^{2}$ One must consider: VILLEY, M 2007, Law and Human rights, Martins Fontes, São Paulo. MUTUA, M 2008, Human rights: a political and cultural critique, University of pennsylvania Press, EUA. SANTOS, B S 2003, For a multicultural conception of human rights. In: SANTOS B S (Ed.) Recognizing for making free: the paths of cultural cosmopolitanism. Civilização Brasileira, Rio de Janeiro.
} 
Mutua (2002, p.10) considers that the human rights movement is marked by a very specific metaphor and that it has a connection with a parallel subtext linked to the great historical narrative of human rights, which portrays a relation between rapists, victims and saviors. This colonialist construction (rapists - victims - saviors) is considered a three-dimensional metaphor in which each dimension reveals a metaphor in itself. For the author, this three-dimensional representation of the corpus of human rights and its discourse would be unidirectional and predictable; a dichotomous construction that necessarily puts what is considered as "good" against what is regarded as "evil."

In this sense, behind the discourses of justice, human rights, democracy, development, and even multiculturalism, in modern rhetoric, it underlies the colonial logic of a Eurocentric epistemology, namely, a standard of knowledge that is imposed as universal and categorizing of humanity. This logic is based on the idea that some (the saviors) are in a universal place, in such a way that they are the representation of the considered universal knowledge (adequate, impartial, equitable, good for all). On the other hand, the "others" (rapist-victims) are those who are in a particular and localized place and therefore should receive this knowledge. Thus, it is possible to find parities in the epistemic control that allowed the development of concepts such as in ferior peoples, barbarians, primitive and underdeveloped.

This colonialist and Eurocentric view defends the idea that Europe - and more contemporaneously with the West - implies the civilizing historical mission (the saviors), in order to remove the rest of humanity from its primitivism (rapist-victims), from its irrationality and of their underdevelopment, to then lead such peoples towards progress and rationality (Dussel, 2005, p. 59).

The first dimension of this prism comprises the wild and evokes images of barbarism. The acts committed by human rights violators are presented as cruel and unimaginable, so that they are represented as the denial of humanity.

In Mutua's view (2002, p.10), the history of human rights presents the state as the classic rapist, a savage permanently committed to consuming humans. Although rape, in human rights discourse, involves much more than just the state, it is portrayed as an operational instrument of rights violations.

States become violators (savages) when they stifle and oppress civil society. The "good" state controls its oppressive tendencies, purifying itself and internalizing human rights. The "bad" state, in turn, is expressed through an anti-liberal, antidemocratic or authoritarian culture. The redemption of the state depends only on its submission to human rights norms. The state is the guarantor of human rights, it is also the target and the raison d'être of human rights norms.

But the reality is much more complex. Although the metaphor may suggest, it is not the state itself that constitutes itself as rapist or barbarian, but its cultural foundation. According to Mutua (2002, p.11), the state only becomes a rights abuser when "bad" culture surpasses or does not allow the development of "good" culture. Thus, the "real" rapist is not the state itself, but a culture diverted from human rights. 
The intrinsic savagery, both theoretically and practically, to the one-party state, to the military junta, to the controlled and closed state, to theocracy, or even that revealed in cultural practices such as female genital mutilation, are not to the state itself. The state as such is neutral, instrumentalizable - a receptacle - that violates rights insofar as it implements the design of a culture of violations.

It is important to emphasize that the conception of modernity was first elaborated, taking into account the contrast with the notion of "primitive", represented not only by the past, but also by the new discoveries, leading to the need for overcoming, consummated by Enlightenment. In this passage from a lower condition to a higher condition, we find, for Mignolo (2010), the condition for the establishment of European epistemic hegemony.

In this picture, it is certain that the production of knowledge implies logically the existence of subjects who have the power to enunciate them and others who are necessarily subject to them, that is, they are limited to the position of mere spectators when not relegated to the condition of objects of knowledge. In this context, some have epistemic credibility (saviors) and others do not have legitimation for theoretical reflections considered as valid (rapist-victim), using Mutua's relational conception.

The official perception of human rights, present in traditional doctrine, is marked by this European liberal theory, which corroborates the theoretical and political elements necessary for the foundation of national states or, in the context of the economic and political relations of the period in question, of the colonial metropolises (Quijano, 2005).

Exactly because of this cultural and historical context, the banner of the universality of human rights remains questioned. This is because the historical understanding of the struggle for human dignity should consider the efforts of societies subjugated by tyranny and European imperialism. Unfortunately, such efforts are not part of the official narrative of human rights.

However, according to Barreto (2013, p. 3) a non-Eurocentric translation of human rights can be carried out by means of a complex process which for this author comprises at least three moments: first, a critique of Eurocentric theory; second, the recovery, reconstruction or consideration of the non-European tradition of values and cultures; and, lastly, the effective realization of a critical dialogue between the different traditions. The first move would be towards stripping the European theory of its alleged universal validity and pointing out that Europe is not the exclusive place from which it is possible to theorize about human rights. Here it is important to clarify that, when the author refers to Europe, he does so taking into account the Habermasian philosophical meaning of the term, for whom this conception includes not only the European continent, but also those countries which have harmonized and developed to a considerable degree the basic patterns of European modernity, such as the United States, Australia, and Japan. Thus, the concept of Europe would be equivalent to that of the West or the Western world.

In recent times, critical views of the standard version of human rights have been developed, which account for the Eurocentric character of their themes, as well as their origins and historiography. 
The alternative proposed by Shivji (1989) involves the understanding of the Discourse of Human Rights and the extension of these rights, through a reconstruction and reconceptualization so that it does not become a part of the dominant project, rather than the liberator, thus recognizing human rights as global and collective rights. Thus, the language of Human Rights should be implemented, articulating the pressing concerns of the vast majority, and at the same time providing a language of resistance against and changing existing conditions. There must be an awareness of the different perspectives of Human Rights, so that one can know how to promote them, in the interests of whom and in what direction.

Therefore, there must be a reconceptualization of human rights, in order to make them an ideology of resistance.

\section{The ISSUE OF MULTICULTURALISM AND hUMAN RightS}

The ethical values of a community vary according to the historical point of view and depend on specific circumstances. If this occurs within the same community, imagine in comparison to the values of different societies. This question is vitally important as regards the debate on the possibility of establishment of universal human rights references for all nations of the globe or not. The search for an ideal of justice must necessarily take into account respect for the other, its history, the context of domination in which it lives or lived, its fullness as a being. This involves considering the cultural ethos. But how to find the right Aristotelian medium? Cançado Trindade (2003) reveals with special propriety that the Vienna Conference of 1993 can be considered as the mark of universalism-relativism tension. Proof of this can be deduced from the characteristically relativistic intervention made by the representative of the Chinese delegation, stating that the historical-cultural aspect of human rights, putting them in tow of the stage of development and own understanding of each country of the same.

In this regard, the statement by China's Nobuo Matsunaga spokesperson:

The concept of human rights is the product of historical development. It is closely linked to specific social, political and economic conditions, and to the specific history, culture, and values of a particular country. Different stages of historical development have different human rights requirements. Countries with different stages of development or with different historical traditions and cultural background also have a different understanding and practice of human rights. (Statement by Nobuo Matsunaga, envoy of the Japanese government and representative of Japan. Vienna, 06/15/1993).

The answer in a diametrically opposite direction would be given by Barroso, representative of the delegation of Portugal, who, in a statement made the following day, argued:

It would be our presumption and a clear abuse to think that instead of recognizing and guaranteeing, the community of States grants or creates 
the rights of men. It follows that the State [...] must respect the rights and dignity of its citizens and can not, in the name of alleged collective, economic, security or other interests, exceed the frontier imposed on it by the very human rights and their primacy over any purpose or function of the State. It can not do so either for reasons of economic power or prosperity, or for reasons which are apparently higher and purer in moral terms, such as religion, ideologies, philosophical or political views. (Statement by Dr. José Manuel Durão Barroso, Minister of Foreign Affairs of Portugal, Vienna, 16.06.1993) and he adds in his statement the fator of what he considers the obviousness of the principle of universality " compatible with the cultural, religious and ideological diversity, assurring that the variety of beliefs, ideas, and human opinions, itself is a richness to defend and has a particular value that it is importante to respect (Barroso, 1993).

He cautions that using the argument of cultural diversity to establish limitations on individual rights, as unfortunately the speeches made were pointing there and beyond, would not be permissible, either in logical or moral terms.

However, history has revealed that morality does not necessarily have to do with the culture of a country. Regardless of the cultural background they have accumulated, countries have already been able to commit real atrocities to their nationals. Examples of this are innumerable, but two examples of distinct cultures seem to be exemplary: Nazism in Germany and the case of the Araguaia disappeared between 1972 and 1975.

It is a fact that Brazil and Germany are very different countries in relation to culture. In Nazi Germany, "the prisoner did not lose only freedom and communication with the outside world. He was stripped of all his possessions: clothes, personal objects, hair, and dental prostheses. He was, above all, emptied of his own being, of his personality" (Comparato, 2001, p. 23).

In Brazil, between 1972 and 1975, the Brazilian Armed Forces undertook campaigns of repression against members of the so-called Guerrilha do Araguaia. In 1973, the President of the General Republic Medici took control over the repressive operations and the official order happened to be of elimination of the captured ones. By the end of 1974, there were no more guerrillas in the Araguaia, and there is information that their bodies were unearthed and burned or thrown into the rivers of the region. The military government put silence on the events of Araguaia and forbade the press to divulge news. In 2010, Brazil was convicted before the Inter-American Court of Human Rights for violating the human rights of political disappears during the military period. In 2014 he was again convicted of enforced disappearances in the period and prepared a report on reparations for the victims until March 2015.

These are just two examples of countries with different cultures that went so far as to violate the human rights of their own nationals. Situations such as these demonstrate, in view of Ramos $(2005,61)$, "the need for an international normative framework in the defense of human rights, which would prevent violations of these rights evaluated by 
domestic law". It is noteworthy that in both situations States were acting in accordance with the law, which had no relation to morality.

Radbruch (1974, p. 415) focuses positivism, and relating his teaching to national laws, he explains that, in these situations (Nazism, Germany and the crime of forced disappearance in Brazil), "positivism was what left defending the people and the lawyers against the most arbitrary, cruel and most criminal laws."

The need for a Universal Declaration of Human Rights is due to the fact that, precisely, there are different cultures that, regardless of the Western point of view, violate human rights. Gorender (2004, p. 21) explains that human rights, despite their universal and universalizing character, were "formalized in the context of the liberal-democratic state, as it developed in the Western European world in the course of the nineteenth century, which proclaimed as inalienable rights of man the rights to life, civil liberties and public liberties."

Leaving the examples of Western countries on the African continent, for example, in some countries, not very different from here, freedom of expression and physical integrity are blocked, since, according to Farias (2016), "there is torture in prisons and there is a heavy-handed police response to public protest."

Cases of human rights violations sound just as affronts to local customs and happen all the time around the world. Look at what happened in Mozambique when "a woman entered a space reserved for boy initiation rites and was 'punished' by order of the person in charge of the ceremony, who ordered a collective violation. She was sexually raped by 17 men." 3

The examples pointed out demonstrate that regardless of the cultural values proper to each community, what is most needed to be preserved is respect for each human being as such.

That is why discussions on the theme of universalism or human rights relativism add up to a new element that concerns differences or equality as considered or discussed in the context of human rights.

Bauman (2003, p. 97) places a particularly lucid position on this alleged polemic, revealing what may at first appear to be an insuperable dichotomy, but which actually contains, at its core, two political projects of linkage and domination. And he goes further by considering that across lines the new neglect of difference is theorized with the recognition of what he calls "cultural pluralism" whose informed and defended politics is known as multiculturalism. For this author, liberal-minded multiculturalism is aimed at

\footnotetext{
${ }^{3}$ Regarding gender-based violence in the name of culture, it is valid to visit the following web site: VIOLATION GRAVE OF HUMAN RIGHTS OF WOMEN IN THE NAME OF TRADITION. Available in: http://www.forumulher.org.mz/index.php/noticias/113-violacao-grave-dos-direitos-humanos-das-mulheresemnome-da-tradicao. Accessed on January 15, 2016.
} 
tolerance both in relation to the rights of communities and the self-affirmation and public recognition of their identities by choice or by tradition. Until then there is no problem. The question arises on the average where, behind an apparent liberality, conservative forces hide their effect on maintaining the status quo of historical inequalities, because they start from the assumption of "it always was like that, so we have to respect".

The moral ugliness of deprivation is miraculously reincarnated in the aesthetic beauty of cultural diversity. What was lost sight of in the process was that the demand for recognition is disarmed unless it is sustained by the practice of redistribution - and that the Community's affirmation of cultural specificity serves little comfort to those who, thanks to the ever greater inequality in the division of resourses, have to accept that they are imposed on them. (Bauman, 2003, p.98).

According to Douzinas (2009, p. 373), "we have the feeling of being surrounded by injustice without knowing where justice lies." A Westerner, for example, may be appalled by certain Indian practices, such as the situation of Dalits, or with the possibility that a Muslim may be married to four women while he lives in a democratic society in which he can only marry a woman. In addition, as an essential observation, we would like to inform you that in Asia there is no expectation of the creation of an Asian Commission or Court of Human Rights to date, nor is there an instrument to protect them (Mazzuoli, 2015, p.156). The main argument is that the Asian reality can not be compared to Western human rights because they are based on individualism, which is inadequate to Eastern societies, which give priority to the community. ${ }^{4}$

There are even countries like China, Singapore and Malaysia that challenge the universalism of human rights. According to Kretschmann (2008, p. 170), "ideas of freedom, equality and democracy were fundamental to the affirmation of human rights in the West." These ideas, however, are not essential in other cultures.

In Hindu view, it is considered not the individual itself, as the starting point, but a complex tote of the real. It differs from the Western view, in which each individual is absolute, irreducible to another, that is, the individual is above the considerations of society and the State. Moreover, the idea of democracy and social order not hierarchically based on it (unlike Hindu caste system) is fundamental to the West. To Hindu view, Western human rights are overly anthropocentric. Kretschmann (2004, p.182) states that in hindu society "order is first valued, and hence the conformity of each element to its role as a whole, to society as a whole. The needs of man are ignored or subordinated to the collective."

\footnotetext{
${ }^{4}$ On this website, we can find more information on the Asian countries' view on the Universality of human rights and the justification by which it does not sign treaties. SILVA, Cristina Gomes da. Perspectivas asiáticas dos Direitos humanos. Available in: http://www.dhnet.org.br/direitos/sip/textos/silva_dh_asia.pdf. Accessed on January 11, 2016.
} 
In Islam, according to Vincent (2001, p. 42), the community of believers takes precedence over the individual, and he must act in a way that preserves his community, such as acknowledging that the community provides the integration of his personality through self-denial and action for the good of the community. Individual rights will remain subject to duties towards the community; Islam adopts the notion of the unity of mankind, but accepts no sovereign other than the authority constituted by reason of faith, so that religion and politics must be led by a sovereign.

From the viewpoint sustained by Kretschmann (2004: 213), "in this sense, some of the greatest obstacles to the practice of human rights and democracy, implying a separate regime of religion, would come from Islam." The Konrad-Adenauer-Stifung Foundation (1998, p.96), considers that the claim that the Islamic religion is incompatible with the idea and practice of human rights is unfounded: "The fundamental difference lies in the fact that in Islam the individual right never is placed absolutely, but there is always in relation to the law before God, every divine creation and before the human creature."

A concrete example of Islamic ideological conflict with the Universal Declaration of Human Rights was with reference to Articles 17 and 19, because Egypt expressed reservations with these articles. Article 17 of the Declaration provides for freedom to marry regardless of race, religion or nationality. In Egypt and in almost all Muslim countries there are restrictions and limitations on the marriage of Muslim women to people belonging to different religions. According to Kretschmann (2004, p. 278), "it is a religious limitation," stresses its representative, adding that, despite such a reservation, such a provision does not hurt universal consciousness, as it does when restricting freedom is based the nationality, race or color of the person."

The Asian opposition to Universal Declaration of Human Rights was primarily concerned with language because of the individualistic, legalistic assertion of Western rights that would be foreign to its moral culture. It was not a disagreement about values, but about articulate form. The Chinese prefer to articulate and defend such rights by a community-based, moral, and appropriate bias of obligations, and by a mutual conviction of a society as a whole (Parekh, 1999, p.155). According to Kretschmann (2008, p. 282), "Asians argued that conventional declarations of human rights prescribe the flags of Western liberal-democratic governments. There should be, for the Chinese, no privilege of the individual over the community."

It is worth noting that at the time of the drafting of the Universal Declaration of Human Rights, "not all members of the United Nations at the time fully shared the convictions expressed in the document: although unanimously approved, the Communist countries (Soviet Union, Ukraine, Czechoslovakia, Poland and Yugoslavia), Saudi Arabia and South Africa abstained from voting" (Comparato 2001, p. 226). The idea of universality was called into question by the lack of unanimity due to ideological conflict.

Currently, there is no national law immune to international human rights norms. In general, States accept the progressive limitation of their sovereignty because they need international cooperation on trade issues and to deal with transboundary problems. 

out that:

On the idea of the universality of human rights, Kretschmann (2008: 274) points

This idea, adopted by the UN General Assembly in the Universal Declaration of 1948, was also called into question by the lack of unanimity, given the abstentions of the Soviet bloc, Saudi Arabia and South Africa, generating three types of challenges to the principle of universality: the ideological conflict, which was expressed in different interpretations of the idea of human rights. These cultural differences constitute the greatest civilizational challenges to Human Rights.

The universality of human rights constitutes a normative claim on the mode of organization of political and social relations in the contemporary world, and not a historical or anthropological fact. Its proponents consider it essential to put a stop to the conduct of bad rulers, which, according to them, would be a solution as Barreto (2010, p.16) proposes for the realization of human rights, so that they go from deontological to ontological, in other words, from the world of duty to the world of being "to make the promise of human rights a reality, it is only necessary to enact them in the laws, to train judges and to indoctrinate the police." And, moreover, to respect differences between countries. This is what the Vienna Declaration sought when it emphasized the importance of respecting the particularities of each sovereign state. Bauman (2003, p.103) follows in its own right when referring to the recognition of cultural variety as a beginning and not the end of the question, insofar as it is a political process of dialogue and negotiation in order to overcome contenders and lower. In discussing the phenomenon of multiculturalism, Taylor (2009, 38) argues that respect for equality requires the imperious respect of the fundamental rights of the individual and recognition of minority cultures, to which Habermas adds the element of the "constitutional democratic state" absent from Taylor's argument. Based on the assumption that the recognition of cultural diversity is a right and a proper starting point for a coherent discussion of the constitutive axiological values human action and able to order it, Habermas element of the constitutional state must be added as a necessary and guiding framework for this debate.

But Bauman (2003, p. 125) goes further and uses the thought of another thinker who transcends the western establisment, namely, Cornellius Castoriadis, adding the elemento "Autonomous society" of his theory of political autonomy; a society is only conceived autonomous insofar as its members are fully autonomous, have freedom of conscience, politically conceived, in the choice of their acts. Reason why this is a political autonomy. Autonomy envisioned within the scope of the polis, in relation to the position of the individual in the nation, or as Bauman prefers "in the republic".

\section{Conclusion}

At the end of this brief essay, let us remember Marx in "On a Jewish question", when he defines that a holistic expression of the individual is the way to display a legitimately conquered, eliminating as possible reductions in the explanation of an emancipation only through strands unique, but fully calculated in all aspects of the founding company. 
There are cases in which the law as conceived and current position, is still governed by the monist and centralizing system of a state model that is still democratic in law, but in a liberal political perspective, objectively, especially in the Brazilian case, it is not managing to obtain a efficient response in terms of social justice that contemplates both cultural transformations and the need to protect the traditions and cultural heritage of the different ethnic groups, especially those used for the globalization of capitalism.

Contradictorily, the State to seek to follow social evolution, and by using the principle of prohibition, without paying attention to the specificities of each cultural aspect, ends up advancing due to those practices performed in social exclusion of the groups it encounters because it does not have rights protected by positive state legal order. Such measured social groups in which they lack protection and guarantees, seek on the basis of human rights or an item of emancipation from the State; legitimized by the human rights body, it can claim or establish rules of rules, many of them prior to the advent status itself, fruits of ancient uses, costumes and traditions, in a universe parallel to the statistical right of registration of a non-state right, but currently since already as a right, although it does not come from the State; even though they recognize the positivized state authority.

These pluralist practices and their efficiency in the reality of the States, as well as the effectiveness of their measures considered as different barriers imposed by the State so that society does not achieve its emancipation.

In addition to the defenders of this anthropological-philosophical conception based on the idea of rationality, human rights are constituted as a moral, legal and political project, a product of modernity in the West, whose experience, maturity and, above all, political authority have accredited it to export or transplant to the rest of the world. That is why the origins of human rights have little or nothing to do with the history and rationality of non-Western peoples.

Amid all these cultural differences, what remains of equality is the fact that a society is made up of people, with equal dignity, with equal value, who are priceless. People of different civilizations have different views on the relations between the symbolic and the men, the individual and the collective, the citizen and the state, parents and children, husband and wife, as well as different views about the relative importance of rights and responsibilities, freedom, authority, equality. Such differences are the result of centuries of history.

What is proposed with this essay is the exercise of a critical reflection on the official narrative of human rights; its limits, although hindering the conjecture of other glances, can not obstruct the perspective towards other paths that allow the necessary reflection towards a human rights movement that is more than a multicultural transcendent to more than universal, that is inclusive and profoundly political.This contribution is to get us to see that human rights cannot hover forevermore above history.

In the face of different views and the fact that states have gone so far as to commit atrocities against their own nationals, there is a need for human rights norms beyond 
dogmatics. Such norms are purposely abstract so that they can be applied more easily in countries, regardless of their respective cultures, but lack effectiveness.

The difficulty in achieving the universality of human rights lies in the fact that there is no absolute morality, but different moral system coexisting with one another.

Rethinking human rights means taking into account the idea of human rights as the product of a development that needs to be inclusive and global, considering the existence and participation of more than one qualified social actor and a society whose sign is solidarity and tolerance process.

This re-elaboration necessarily involves a multiplicity of actors whose contribution, both culturally and socially, will be of fundamental importance for changing the conception, direction and objectives of human rights. The fulfillment of norms concerning human rights, even when these are not in keeping with the culture of their country, leads to the conclusion that in this action lies a true moral content, which in Kant's eyes means the fulfillment is not for duty, but out of duty. This respect is essential as globalization advances every day and respect for human rights is a positive factor on the international stage, facilitating cooperation between the various States.

\section{REFERENCES}

BAXI, U 2006, Politics of Reading human rights: inclusion and exclusion within the production of human rights, in The legalization of Human Rights, Routledge, London.

BARRETO, V P 2010, O fetiche dos direitos humanos e outros temas, Lumen Juris, Rio de Janeiro,.

BOBBIO, N 1992, A era dos Direitos, Campus, São Paulo.

CANÇADO TRINDADE, A A, 2003, Tratado de direito internacional dos direitos humanos, Fabris, Porto Alegre.

CASO GOMES LUND e outros versus Brasil. Accessed14 january 2018, <http://www. direitoshumanos.gov.br/sobre/sistemasint/lund.pdf $>$.

COMPARATO, F K 2001, A afirmação histórica dos direitos humanos, Saraiva, São Paulo.

COMPARATO, F K 2000, 'Fundamentos dos direitos humanos', Revista Consulex, vol. 48, dez.

COSTA D 2009, O fim dos direitos humanos, Unisinos, São Leopoldo.

DONNELLY, J 2006, 'The virtue of legalization'. The legalization of Human Rights, Routledge, London, pp. 67-80.

DURANTI, M. 2017, 'The Conservative Human Rights Revolution European Identity, Transnational Politics, and the Origins of the European Convention', Oxford University Press. 
DWORKIN, R 2000, Uma questão de princípio, Martins Fontes São Paulo.

FARIA, P. Violações de direitos humanos na África. Accessed 15 january 2018, $<$ http://www.voanews.com/portuguese/news/a-38-2008-05-28-voa2-92244494. html>.

FERNANDEZ, E 1991, Teoría de la justicia y derechos humanos. Editorial Debate, Madrid.

FUNDAÇÃO KONRAD-ADENAUER-STIFUNG 1998, Cinquenta anos da Declaração Universal dos Direitos Humanos, Centro de Estudos, São Paulo, nº 11.

GORENDER, J 2004, Direitos humanos: o que são (ou devem ser), Senac São Paulo.

KANT, I 1995, Fundamentação da metafísica dos costumes. Porto Editora, Portugal.

KELSEN, H 2011. Teoria pura do direito, Martins Fontes, São Paulo.

KRETSCHMANN, A 2008 Universalidade dos Direitos humanos e diálogo na complexidade de um mundo civilizacional, Juruá, Curitiba.

MAZZUOLI, V O. 2015, Curso de Direitos humanos, Método, São Paulo.

MOYN S. 'Christian Human Rights', 2015.University of Pennsylvania Press.

MUTUA, M 2008, Human Rights A Political and Cultural Critique, University of Pennsylvania Press, EUA.

NINO, C S 1989, Ética y derechos humanos: un ensayo de fundamentación, Ariel, Barcelona.

PAREKH, B 1999, 'Non-ethnocentric universalism', Dunne, T, Wheeler, N J, Human rights in global politics, Cambridge University, New York.

QUIJANO, A 2005, 'Colonialidade do poder, eurocentrismo e América Latina', A colonialidade do saber: eurocentrismo e ciências sociais. Perspectivas latinoamericanas, Edgardo L, Colección Sur Sur, CLACSO, Ciudad Autónoma de Buenos Aires, Argentina. Setembro. pp.227-278.

RADBRUCH, G 1974, Filosofia do Direito, Armênio Amado Editor, Coimbra.

RAMOS, A C 2005, Teoria geral dos direitos humanos na ordem internacional.: Renovar, Rio de Janeiro.

SILVA, C G, Perspectivas asiáticas dos Direitos humanos. Accessed 11 january 2018, $<\mathrm{http}: / /$ www.dhnet.org.br/direitos/sip/textos/silva_dh_asia.pdf $>$.

SHIVJI, IG 1989, The Concept of Human Rights in Africa, Council for the Development of Economic and Social Research in Africa (CODRESIA Book Series), London.

TAYLOR, C 2009, El multiculturalismo y la política del reconocimiento, Fondo de cultura económica, México.

VICENT, R J 2001. Human rights and international relations. Cambridge University, Cambridge 
VIOLAÇÃO GRAVE DOS Direitos Humanos Das Mulheres Em Nome Da Tradição. Accessed 15 january $2018<$ <ttp://www.forumulher.org.mz/index.php/noticias/ 113-violacaograve-dos-direitos-humanos-das-mulheres-em-nome-da-tradicao $>$.

Received: July $10^{\text {th }} 2019$

Accepted: November $27^{\text {th }} 2019$ 